\title{
THE BULHOEK MASSACRE: ORIGINS, CASUALTIES, REACTIONS AND HISTORICAL DISTORTIONS
}

\author{
D.H. MAKOBE \\ DOCUMENTATION SERVICE DIRECTORATE, SANDF
}

\section{Introduction}

The Bulhoek massacre remains a standard feature in accounts of South African history. Historians who wrote on the incident before the birth of the Popular or Peoples history movement and evidence submitted to Sir Thomas Graham, the presiding judge at the trial of the Israelites, made it clear beyond all doubt that the Israelites were religious fanatics who were driven by their fanaticism and blind faith in Enoch Mgijima's words to attack the Police. In the 1980s, with the birth of the Popular history movement, the massacre was reinterpreted by social historians, especially those associated with the University of Witwatersrand (Wits) History Workshop to fit into the perspective of the Popular history approach. The Israelites were seen as political heroes who stood against an oppressive system. The two different approaches to the massacre leads to the historical distortions of the event.

The writer's research attempts to correct such distortions. His analysis of the event is divided into a series of four articles. The first article is entitled: Confrontation with the Police: The Israelites of Enoch Mgijima and the Bulhoek massacre of 24 May 1921. The article focuses on the origins of the Israelites, their confrontation with the authorities over their illegal squatting at Bulhoek and the events of 24 May 1921. The second article is entitled: The price of fanaticism: the casualties of the Bulhoek massacre. It focuses on the casualties of the massacre on the side of the Israelites and shows that the high number of Israelites who lost their lives during the incident was due to their fanaticism. The article further tries to establish a reliable figure on the basis of available sources as to how many Israelites lost their lives during their attack. The third article is entitled: Understanding Bulhoek massacre: voices after the massacre and down the years. The article focuses on the reactions from different political organisations, the Union Government, people who lived in the vicinity of Queenstown at the time, as well as the views of the general public at the time. In order to take the reader back to the period immediately after the massacre, a lot of quotations is used. The last article is entitled: Religious fanatics that became political heroes: The historical distortions of the Bulhoek massacre. This article shows how the Bulhoek massacre was distorted by historians, especially within the context of the Peoples history approach. 
LAWRENCE, G.G.J., "Echoes of War 1915-1918 (Part 2)". Militaria 8(2), 1978.

BETTERIDGE, A.H., Combat in and over Delville Wood, vol. 1. Unpublished Manuscript.

BROWN, M., The Imperial War Museum Book of the First World War. London, Sidgwick \& Jackson, 1993.

BROWN, M., The Imperial War Museum Book of the Western Front. London, Sidgwick \& Son, 1993.

BUCHAN, J., The History of the South African Forces in France. London, Thomas Nelson \& Sons LTD., 1920.

DIGBY, P.K.A., Pyramids and Poppies: The 1st SA Infantry Brigade in Libya, France and Flanders 1915-1919. Rivonia, Ashanti Publishing (Pty) Ltd, 1993.

EWING, J., The History of the 9th (Scottish) Division, 1914-1919. London, John Murray, 1921.

KAPLAN, H.I. \& B.J. SADOCK a.o. (eds.), Synopsis of Psychiatry: Behavioral Sciences Clinical Psychiatry, 6th. ed. London, Williams \& Wilkins, 1991.

LAWSON, J.A., Memories of Delville Wood, South Africa's Great Battle. Cape Town, T. Maskew Miller, 1918.

MCMANNERS, H., The Scars of War. London, Harper
Collins Publishers, 1994.

NÖTHLING, C.J., Suid-Afrika in die Eerste Wêreldoorlog (1914-1918). Silverton, Suid-Afrikaanse MilitêrHistoriese Konsultante, 1994.

SOLOMON, E., Potchefstroom to Delville Wood (with the 3rd South African Infantry): Together with some experiences as a Prisoner of War in Germany. Johannesburg, Football \& Sports Publishers, nd.

The story of Delville Wood told in letters from the front. Cape Town, Cape Times Limited, nd.

The War Office, Statistics of the Military Effort of the British Empire during the Great War, 1914-1920. London, His Majesty's Stationery Office, 1922.

UYS, I., Rollcall: The Delville Wood Story. Johannesburg, Uys Publishers, 1991.

WARWICK, G.W., We band of brothers: Reminiscences from the 1st S.A. Infantry Brigade in the 1914-1918 War. Cape Town, Howard Timmins, 1962.

Documentation Service Directorate (SANDF Archives): Pamphlet Collection, Box 108, WOI: Libië, lerse rebelle, lugoorlog ens. 